\title{
PENERAPAN MODEL PEMBELAJARAN KOOPERATIF TIPE TGT (TEAMS GAMES TOURNAMENT) UNTUK MENINGKATKAN MOTIVASI DAN HASIL BELAJAR PESERTA DIDIK
}

\author{
Dewi Qurrota A'yuningsih,S.Pd 1, ${ }^{*}$, Dr. I Nyoman Suardana², I Made Suwenten,S.Pd³
}

${ }^{1}$ Universitas Pendidikan Ganesha

${ }^{2}$ Universitas Pendidikan Ganesha

${ }^{3}$ SMA Negeri 3 Singaraja

\begin{abstract}
Abstrak
Penelitian ini bertujuan untuk meningkatkan motivasi dan hasil belajar peserta didik kelas X MIA 2 SMAN 3 Singaraja Tahun Ajaran 2016/2017 melalui penerapan model pembelajaran kooperatif tipe TGT (Teams Games Tournament). Jenis penelitian ini adalah penelitian tindakan kelas. Pengukuran motivasi belajar peserta didik didasarkan pada hasil angket motivasi belajar peserta didik dan didukung oleh hasil lembar observasi motivasi peserta didik. Sedangkan pengukuran hasil belajar peserta didik didasarkan pada tes hasil belajar yang dilaksanakan setiap akhir siklus untuk mengetahui ada tidaknya peningkatan. Data yang diperoleh dalam penelitian ini dianalisis secara deskriptif kuantitatif. Hasil penelitian menujukkan bahwa Penerapan model pembelajaran kooperatif tipe TGT dalam pembelajaran kimia dapat meningkatkan motivasi dan hasil belajar peserta didik kelas X MIA 2 SMA Negeri 3 Singaraja Tahun Ajaran 2016/2017 dengan persentase rata-rata motivasi belajar dari pra penelitian hingga siklus 2 , yaitu $51,15 \%$ menjadi $60,73 \%$ pada siklus 1 dan menjadi $76,5 \%$ pada siklus 2 . Hasil tes belajar peserta didik juga mengalami peningkatan dari $32 \%$ pada siklus satu menjadi $84 \%$ pada siklus dua. Peningkatan motivasi dan hasil belajar peserta didik didukung dengan data persentase keseluruhan hasil angket respon peserta didik terhadap model pembelajarn kooperatif tipe TGT, yaitu sebanyak 85,52\%. Penerapan model kooperatif tipe TGT dapat digunakan sebagai salah satu alternatif model pembelajaran bagi guru dalam proses pembelajaran. Namun, model pembelajaran ini membutuhkan waktu yang lebih banyak dalam proses pembelajarannya karena adanya permainan. Maka dari itu, guru dituntut untuk bisa membagi waktu dalam penyampaian materi yang sesuai dengan indikator pencapain kompetensi.
\end{abstract}

\author{
Kata-kata kunci: \\ Model pembelajaran \\ kooperatif tipe TGT, \\ motivasi belajar, dan hasil \\ belajar
}

\section{Pendahuluan \\ Kurikulum yang berlaku saat ini adalah kurikulum 2013. Kurikulum ini mengubah proses pembelajaran yang awalnya teacher center menjadi student center sehingga peserta didik dituntut lebih aktif dalam proses pembelajaran dan guru hanya sebagai fasilitator. Pembelajaran yang sesuai dengan kurikulum 2013 adalah pembelajaran yang menggunakan pendekatan saintifik dengan tahapan $5 \mathrm{M}$, yaitu}

mengamati, menanya, mengumpulkan informasi, mengasosiasi, dan mengkomunikasikan. Penerapan pendekatan saintifik tersebut untuk semua mata pelajaran, termasuk Kimia.

Ilmu kimia berkembang melalui eksperimen sehingga berisi tentang produk dan proses ilmiah serta penerapannya untuk meningkatkan kesejahteraan manusia. Ilmu kimia dipelajari dan dikembangkan dengan 
metode ilmiah. Oleh karena itu, ilmu kimia memiliki peranan penting dalam peningkatan mutu pendidikan khususnya menghasilkan peserta didik yang berkualitas, yaitu peserta didik yang mampu berfikir kritis, kreatif, logis dan berinisiatif dalam mempelajari struktur, sifat, dan perubahan materi, serta energi yang menyertai perubahan materi. Namun, sebagian besar peserta didik SMA menganggap materi kimia merupakan materi yang sulit dipelajari. Banyak konsep baru yang diterima peserta didik, perhitungan yang rumit, dan materi yang bersifat abstrak merupakan permasalahan yang sering diungkap peserta didik tentang kimia.

Hasil observasi terhadap peserta didik kelas X MIA 2 di SMA Negeri 3 Singaraja menunjukkan bahwa hanya sebagian kecil dari peserta didik yang aktif dalam mengikuti proses pembelajaran kimia terutama pada saat tahap menanya dan mengasosiasi yang menuntut peserta didik untuk mampu menyampaikan pertanyaan tentang materi kimia yang akan dipelajari dan saling berdiskusi dengan kelompoknya dalam menyelesaikan permasalahan yang diberikan oleh guru. Hal tersebut dapat mengindikasikan kurangnya motivasi peserta didik dalam belajar kimia.

Motivasi peserta didik dalam belajar kimia terbilang belum cukup tinggi. Hal tersebut dibuktikan dengan hasil angket motivasi dan didukung dengan hasil UTS peserta didik. Secara umum, tingkat motivasi belajar peserta didik akan berbanding lurus dengan hasil belajarnya. Hasil angket motivasi yang diberikan kepada peserta didik kelas X MIA 2 di SMAN 3 Singaraja menunjukkan bahwa persentase rata-rata motivasi peserta didik secara klasikal sebesar 51,15 \% yang termasuk dalam kategori sedang. Sedangkan hasil UTS menunjukkan bahwa dari 25 orang peserta didik, hanya 16\% siswa yang tuntas atau mencapai nilai KKM, yaitu 75 dengan nilai rata-rata hasil UTS sebesar 48,48. Nilai rata-rata yang kecil dan sedikitnya peserta didik yang tuntas dalam mata pelajaran kimia menunjukkan bahwa perlunya penanganan khusus terkait dengan motivasi belajar peserta didik.

Dalam angket motivasi terdapat kolom komentar tentang cara mengajar guru. Tujuannya untuk mengetahui tanggapan peserta didik tentang cara mengajar guru kimia. Beberapa siswa berkomentar bahwa mereka menginginkan adanya permainan dalam pembelajaran sehingga peserta didik lebih semangat dan tidak bosan karena metode yang digunakan selalu sama. Salah satu model pembelajaran yang dapat menerapkan 5M dalam proses pembelajaran sekaligus terdapat permainan di dalamnya adalah model pembelajaran kooperatif tipe TGT (Teams Games Tournaments). Model pembelajaran kooperatif tipe TGT merupakan model pembelajaran kooperatif yang menempatkan peserta didik dalam kelompok-kelompok kecil yang bersifat heterogen dan setiap peserta didik berperan aktif dalam pembelajaran yang dikemas dalam bentuk turnamen akademik untuk memperoleh skor. Pengemasan pembelajaran ke dalam sebuah turnamen akademik inilah yang membedakan TGT dengan tipe model pembelajaran kooperatif lainnya.

Berdasarkan uraian latar belakang di atas, maka peneliti ingin mengadakan penelitian tindakan kelas yang mampu meningkatkan motivasi dan hasil belajar peserta didik yang tetap menggunakan pendekatan saintifik (5M) sekaligus diselingi dengan permainan. Penelitian tersebut tentang penerapan model pembelajaran kooperatif tipe TGT (Teams Games Tournaments) untuk meningkatkan motivasi dan hasil belajar peserta didik kelas X MIA 2 SMAN 3 Singaraja pada mata pelajaran Kimia Tahun Ajaran 2016/2017.

\section{Metode}

Jenis penelitian ini adalah PTK (Penelitian Tindakan Kelas) berupa penelitian yang bersifat deskriptif kuantitatif. Subyek penelitian ini adalah peserta didik kelas X MIA 2 SMA N 3 Singaraja Tahun Ajaran 2016/2017 sebanyak 25 orang, terdiri dari 15 orang perempuan dan 10 orang laki-laki dengan kemampuan yang heterogen. Objek penelitian ini adalah motivasi dan hasil belajar peserta didik. Desain penelitian mengacu pada model Kemmis dan M.C Taggart, yang terdiri dari 4 komponen, yaitu: (1) perencanaan tindakan, (2) pelaksanaan tindakan, (3) observasi, dan (4) refleksi.

Sesuai dengan diagram di atas, maka penelitian diawali dengan rencana tindakan. Pada saat rencara tindakan, peneliti menyiapkan instrumen untuk menggali informasi awal tentang kondisi kelas dan peserta didik dalam proses pembelajaran kimia, diantaranya melakukan wawancara dengan guru mata pelajaran tentang kondisi peserta didik dan sekolah lalu memberikan angket motivasi belajar peserta didik. Setelah menemukan masalah dalam kelas, peneliti memilih tindakan yang akan dilakukan untuk mengatasi masalah tersebut. Setelah persiapan tindakan berupa penyiapan perangkat pembelajaran maka tahap selanjutnya adalah pelaksanaan tindakan. Kemudian dilakukan observasi terhadap motivasi belajar peserta didik selama proses pembelajaran dan tes untuk mengetahui hasil belajar peserta didik. Tahap berikutnya adalah 
refleksi dari hasil penelitian yang telah dilakukan. Pada tahap ini, hasil refleksi seperti kendala-kendala yang terjadi selama pelaksanaan penelitian akan diperbaiki untuk siklus selanjutnya.

Siklus akan berakhir apabila melalui penerapan model pembelajaran kooperatif tipe TGT (Teams Games Tournaments) dapat meningkatkan motivasi dan hasil belajar peserta didik kelas X MIA 2 SMA N 3 Singaraja yang ditunjukkan dengan data hasil angket motivasi dan hasil tes belajar atau setelah dilakukan minimal dua siklus tidak menunjukkan adanya perubahan pada motivasi dan hasil belajar peserta didik.

Refleksi awal dilakukan peneliti dengan mengumpulkan informasi mengenai cara mengajar guru, kesulitan yang dialami, dan nilai KKM pelajaran kimia untuk kelas X serta sarana pendukung pembelajaran yang dimiliki sekolah. Informasi diperoleh dari guru mata pelajaran kimia di SMA N 3 Singaraja, yaitu bapak I Made Suwenten, S.Pd.

Hasil pengumpulan informasi tersebut adalah guru telah menggunakan pendekatan saintifik (5M) yang sesuai dengan kurikulum 2013 dalam mengajar khususnya untuk kelas X, tetapi peserta didik masih menunjukkan kurangnya semangat saat pelajaran berlangsung. Terutama pada saat fase menanya. Peserta didik membutuhkan waktu yang lama hanya untuk membuat pertanyaan dan diskusi berjalan sangat lambat. Nilai KKM untuk pelajaran kimia di kelas X adalah 75. Di sekolah sudah terdapat in focus sebagai penunjang pembelajaran walaupun jumlahnya hanya 2 dan terdapat laboratorium kimia yang sudah cukup lengkap peralatannya.

Berdasarkan informasi yang dikumpulkan maka peneliti merencanakan tindakan mencoba model pembelajaran kooperatif tipe TGT. Upaya ini dilakukan supaya motivasi dan hasil belajar peserta didik mengalami peningkatan. Untuk memperoleh data yang lebih valid, peneliti menggunakan instrumen pengumpulan data berupa angket motivasi belajar peserta didik, lembar observasi motivasi, instrumen hasil belajar siswa, dan angket respon peserta didik. Hasil observasi yang telah dilakukan, dianalisa sebagai bentuk refleksi diri tentang kekurangan-kekurangan selama proses pembelajaran menggunakan model pembelajaran kooperatif tipe TGT. Hasil analisa yang dilakukan dalam tahap ini akan digunakan sebagai acuan untuk merencanakan siklus berikutnya. Dalam tahap ini, peneliti memperbaiki kekurangan-kekurangan dari pelaksanaan pembelajaran sebelumnya berdasarkan hasil refleksi pada siklus 1 .
Kegiatan yang akan dilakukan dalam tahap ini adalah melaksanakan skenario pembelajaran yang telah diperbaiki. Seperti pada siklus 1, Observasi dilakukan dengan menggunakan lembar observasi terhadap motivasi belajar peserta didik pada saat pembelajaran berlangsung sesuai dengan indikator atau tujuan yang ingin dicapai. Pada akhir siklus, peserta didik kembali diminta untuk mengisi angket motivasi, melakukan tes hasil belajar yang akan dibandingkan dengan nilai awal peserta didik pada materi sebelumnya untuk mengetahui adanya peningkatan, dan mengisi angket respon peserta didik terhadap model pembelajaran kooperatif tipe TGT.

Hasil observasi yang telah dilakukan, dianalisa dan dibandingkan dengan hasil observasi pada siklus 1 untuk mengetahui peningkatan motivasi dan hasil belajar peserta didik. Hasil analisa yang dilakukan dalam tahap ini akan digunakan sebagai ukuran tingkat keberhasilan akhir dari penggunaan model pembelajaran kooperatif tipe TGT dalam meningkatkan motivasi dan hasil belajar peserta didik.

Instrumen penelitian yang digunakan adalah (1), Lembar wawancara, berisi tentang informasi yang ingin diketahui peneliti tentang cara mengajar guru, kesulitan yang dialami, dan KKM pada pelajaran kimia untuk kelas $X$ serta sarana pendukung pembealajaran yang dimiliki sekolah (2), Angket Motivasi Belajar Pra Penelitian, diberikan kepada peserta didik sebelum penelitian dilakukan. Angket motivasi belajar terdiri dari 35 pernyataan, baik pernyataan negatif maupun positif dan kolom komentar tentang cara guru mengajar. Dari 35 pernyataan tersebut, peserta didik diminta untuk memilih jawaban yang sesuai dengan pemikirannya. (3), Lembar Observasi Motivasi Belajar Peserta Didik, digunakan untuk menilai kegiatan peserta didik yang berhubungan dengan indikator motivasi belajar selama proses pembelajaran berlangsung. (4), Angket Motivasi Belajar Pasca Penelitian, diberikan kepada peserta didik setelah penelitian dilakukan. Angket motivasi belajar terdiri dari 35 pernyataan, baik pernyataan negatif maupun positif yang disesuaikan dengan indikator motivasi belajar. (5), Lembar tes hasil belajar peserta didik, digunakan untuk mengukur kemampuan peserta didik dalam memahami materi pelajaran dan memperoleh informasi tentang sejauh mana pengaruh penerapan model pembelajaran kooperatif tipe TGT terhadap hasil belajar siswa. Bentuk tes ini berupa pilihan ganda dan uraian. (6), Angket respon peserta didik, diisi oleh peserta didik dan digunakan untuk memperoleh data mengenai respon 
peserta didik terhadap penerapan model pembelajaran kooperatif tipe TGT. Dalam angket, terdapat 14 pernyataan. Berdasarkan pernyataan dalam angket, peserta didik diminta untuk memilih jawaban dengan cara memberikan tanda checklist $(\sqrt{ })$ pada jawaban yang sesuai dengan keadaannya.

Metode pengumpulan data yang digunakan adalah sebagai berikut: (1) Wawancara dengan guru kimia, Digunakan untuk mengetahui kondisi awal sekolah khususnya mengumpulkan informasi mengenai cara mengajar guru, kesulitan yang dialami, dan KKM pada pelajaran kimia untuk kelas X serta sarana pendukung pembealajaran yang dimiliki sekolah. Wawancara dapat dilakukan secara face to face atau by phone. (2) Angket motivasi belajar pra penelitian Angket motivasi belajar pra penelitian ini diberikan sebelum penelitian dilakukan dan digunakan untuk sebagai pengetahuan awal peneliti tentang tingkat motivasi belajar peserta didik. Hasil perhitungan angket motivasi belajar akan dibandingkan dengan hasil perhitungan angket motivasi belajar pasca penelitian untuk mengetahui adanya peningkatan. (3)Observasi Motivasi Belajar Peserta Didik, dilakukan selama proses pembelajaran berlangsung sesuai dengan indikator atau tujuan yang ingin dicapai. (4)Angket Motivasi Belajar Pasca Penelitian akan dibandingkan dengan hasil perhitungan angket motivasi belajar pra penelitian yang selanjutnya digunakan untuk mengetahui peningkatan motivasi belajar peserta didik setelah diterapkan model pembelajaran kooperatif tipe TGT. (5) Tes hasil belajar peserta didik, digunakan untuk mengetahui kemampuan peserta didik dan tingkat keberhasilan penerapan model pembelajaran kooperatif tipe TGT dalam meningkatkan hasil belajar siswa. (6)Penyebaran Angket Respon Peserta Didik, dilakukan dengan tujuan untuk mengetahui respon peserta didik terhadap penerapan model pembelajaran kooperatif tipe TGT dalam meningkatkan motivasi dan hasil belajar peserta didik.

Teknik Analisis Data dan Indikator Keberhasilan diantaranya adalah: (1)Wawancara guru kimia dianalisis secara deskriptif kualitatif, yaitu dengan mendeskripsikan tentang kondisi belajar, peserta didik, dan sekolah sebagai acuan dalam menyusun langkah pembelajaran. (2)Angket Motivasi Belajar Pra Penelitian dianalisis secara deskriptif kuantitatif, yaitu memberi penilaian tentang tingkat motivasi belajar peserta didik sebelum diterapkan model pembelajaran kooperatif tipe TGT. Analisis dilakukan menggunakan skala Likert. Data dari hasil penilaian skor pada media dianalisis dengan menggunakan rumus:

Hasil ini sebagai data awal tingkat motivasi belajar peserta didik yang selanjutnya akan dibandingkan dengan hasil angket motivasi belajar pasca penelitian untuk mengetahui adanya peningkatan. (3), Observasi Motivasi Belajar Peserta Didik dilaksanakan pada setiap pertemuan selama proses pembelajaran kimia. Hasil observasi motivasi belajar peserta didik dianalisis secara deskriptif kuantitatif, yaitu memberi penilaian tentang tingkat motivasi belajar peserta didik selama diterapkan model pembelajaran kooperatif tipe TGT. Analisis dilakukan menggunakan skala Likert. Data dari hasil penilaian skor dari lembar observasi motivasi peserta didik dianalisis dengan menggunakan rumus:

$$
\begin{aligned}
& \text { Persentase }(\%)=\frac{\text { nilah shor total }}{\text { wh shor maksimal }} \quad \mathrm{x} \\
& 100 \%
\end{aligned}
$$

Skor maksimal $=$ skor tertinggi $\mathrm{x}$ jumlah indikator motivasi

Kriteria yang dipakai seperti pada tabel 3.1. Berdasarkan kriteria persentase tersebut, motivasi belajar peserta didik dikatakan tinggi apabila persentase motivasi belajar peserta didik rata-rata sebesar $\geq 61 \%$.

Penelitian ini dikatakan berhasil apabila jika persentase motivasi belajar peserta didik secara klasikal mengalami peningkatan dari setiap siklusnya dan termasuk dalam kriteria tinggi. (4) Angket Motivasi Belajar Pasca Penelitian diberikan pada setiap akhir siklus. Hasil angket motivasi belajar pasca penelitian dianalisis secara deskriptif kuantitatif, yaitu memberi penilaian tentang tingkat motivasi belajar peserta didik setelah diterapkan model pembelajaran kooperatif tipe TGT. Analisis dilakukan seperti cara menganalisis angket motivasi belajar pra penelitian, yaitu dengan menggunakan skala Likert. Hasil akhir berupa perbandingan antara hasil angket motivasi belajar pra penelitian dengan hasil angket motivasi belajar pasca penelitian untuk mengetahui adanya peningkatan. Penelitian ini dikatakan berhasil apabila persentase motivasi belajar peserta didik mengalami peningkatan dari setiap siklusnya dan termasuk dalam kriteria tinggi. (5), Tes hasil belajar dilaksanakan pada setiap akhir siklus. Hasil tes hasil belajar dianalisis secara deskriptif kuantitatif, yaitu memberi penilaian tentang penguasaan materi setelah diterapkan model pembelajaran kooperatif tipe TGT. Analisis dilakukan dengan menggunakan pendekatan PAP (Penilaian Acuan Patokan) dengan langkah-langkah sebagai berikut. (a), Menentukan terlebih dahulu persentase minimal pengusaan materi. Hal ini 
disesuaikan dengan nilai KKM, yaitu 75, (b) Menentukan nilai-nilai berdasarkan standar nilai seperti tabel berikut ini. Peserta didik dinyatakan tuntas apabila nilai tes hasil belajar mencapai nilai 75 dengan predikat $\mathrm{C}$.

Penelitian ini dikatakan berhasil apabila nilai tes hasil belajar mengalami peningkatan dengan persentase ketuntasan belajar secara klasikal sebesar 75\%. Perhitungan persentase ketuntasan peserta didik secara klasikal dihitung menggunakan rumus :

Persentase ketuntasan

$$
(\%)=\frac{\text { ah peserta didik yang tuntas }}{\text { jumiah peserta didik }} \times 100
$$

Sedangkan untuk mengetahui peningkatan nilai rata-rata peserta didik secara klasikal pada setiap siklus maka digunakan perhitungan (Nana Sudjana, 2004) Hasil tes belajar ini akan dibandingkan dengan hasil tes belajar peserta didik sebelum diterapkannya model pembelajaran kooperatif tipe TGT untuk mengetahui adanya peningkatan. (6), Angket respon siswa dianalisis secara deskriptif kuantitatif, yaitu memberi penilaian tentang penerapan model pembelajaran kooperatif tipe TGT dengan persentase. Pemberian skor dalam angket ini didasarkan pada jenis pernyataan.

\section{Hasil}

Pelaksanaan tindakan siklus 1 dilaksanakan selama tiga kali pertemuan. Satu kali pertemuan terdiri dari tiga jam pelajaran (3 $\mathrm{x} 45$ menit). Pertemuan pertama dan kedua merupakan tahap penyampaian materi pembelajaran, sedangkan pertemuan ketiga digunakan untuk tes belajar dan penyebaran angket motivasi belajar peserta didik.

Sebelum melakukan penelitian di dalam kelas, peneliti meyiapkan RPP, LKPD, lembar observasi motivasi belajar peserta didik, dan instrumen penilaian. Selain itu, peneliti juga membuat kelompok diskusi baru sebanyak lima kelompok yang terdiri dari lima peserta didik dengan kemampuan heterogen untuk masingmasing kelompok.

Lembar observasi motivasi belajar diberikan kepada observer dengan tujuan memudahkan guru dalam mengamati aktivitas peserta didik sesuai dengan indikator motivasi. Terdapat tiga observer yang ikut terlibat selama proses pembelajaran. Karena jumlah kelompoknya hanya lima maka dua observer mengamati empat kelompok dan satu observer mengamati satu kelompok sekaligus membuat dokumentasi pembelajaran. Untuk memudahkan observer dalam mengamati, maka setiap peserta didik menggunakan nomor absen yang diletakkan di bahu kanannya.

Materi yang diajarkan pada pertemuan pertama dalam siklus 1 adalah materi perkembangan sistem periodik unsur. Sedangkan materi yang diajarkan pada pertemuan kedua adalah sifat keperiodikan unsur. Proses pembelajaran di kelas berjalan sesuai dengan RPP yang menggunakan model pembelajaran kooperatif tipe TGT. Model pembelajaran kooperatif tipe TGT memiliki enam fase, yaitu menyampaikan tujuan dan motivasi peserta didik, menyajikan informasi, mengorganisasikan peserta didik ke dalam kelompok belajar, membimbing kelompok bekerja dan belajar, evaluasi, penghargaan kelompok. Tahapan-tahapan tersebut tetap mengacu pada pendekatan saintifik (5M). Yang menjadi ciri dari tipe TGT adalah adanya permainan. Permainan dilakukan pada tahap membimbing kelompok bekerja dan belajar. Setelah peserta didik mengkomunikasikan hasil diskusi kelompoknya, maka permainan dapat dimulai.

Guru menginformasikan aturan permainan terlebih dahulu. Dalam permainan, terdapat tiga kelompok. Peserta didik dengan kemampuan kognitif tertinggi di kelompoknya berkumpul dalam Kelompok A. Peserta didik dengan kemampuan kognitif menengah di kelompoknya berkumpul dalam Kelompok B. Peserta didik dengan kemampuan kognitif rendah di kelompoknya berkumpul dalam Kelompok C. Kelompok A, B, C diberi soal sesuai dengan tingkat kognitifnya. Setiap anggota dalam kelompok A, B, C akan saling bersaing mengerjakan soal untuk memberikan poin kepada kelompoknya. Kelompok dengan poin tertinggi akan menjadi pemenang permainan. Pemenang akan mendapatkan penghargaan dari guru pada saat penutup tahap penghargaan kelompok.

Berikut ini adalah hasil observasi motivasi belajar peserta didik pada pertemuan pertama dan kedua.

Tabel 1. Hasil Observasi Motivasi Belajar Peserta Didik pada Siklus 1

\begin{tabular}{|c|c|c|c|c|c|}
\hline \multirow[b]{2}{*}{ No. } & \multirow[b]{2}{*}{ Kriteria } & \multicolumn{2}{|c|}{ Pertemuan ke-1 } & \multicolumn{2}{|c|}{ Pertemuan ke-2 } \\
\hline & & $\begin{array}{c}\text { Jumlah Peserta } \\
\text { Didik }\end{array}$ & $\begin{array}{c}\text { Persentase } \\
(\%)\end{array}$ & $\begin{array}{c}\text { Jumlah Peserta } \\
\text { Didik }\end{array}$ & $\begin{array}{c}\text { Persentase } \\
(\%)\end{array}$ \\
\hline 1 & $\begin{array}{l}\text { Sangat } \\
\text { Tinggi }\end{array}$ & 0 & 0 & 2 & 8 \\
\hline 2 & Tinggi & 4 & 16 & 7 & 28 \\
\hline
\end{tabular}




\begin{tabular}{cccccc}
\hline 3 & Sedang & 21 & 84 & 17 & 68 \\
4 & Rendah & 0 & 0 & 0 & 0 \\
5 & Sangat & 0 & 0 & 0 & 0 \\
\hline
\end{tabular}

Berdasarkan tabel 1, pada pertemuan pertama dalam siklus satu, hasil observasi terhadap motivasi belajar peserta didik menunjukkan bahwa sebanyak $84 \%$ peserta didik yang memiliki motivasi belajar kimia sedang dan hanya $16 \%$ peserta didik yang memiliki motivasi belajar kimia tinggi. Pada pertemuan kedua, jumlah peserta didik yang memiliki motivasi belajar kimia tinggi mengalami peningkatan menjadi $28 \%$ sedangkan jumlah peserta didik yang memiliki motivasi belajar kimia sedang mengalami penurunan menjadi 68\%. Selain itu, sebanyak $8 \%$ peserta didik yang telah memiliki motivasi belajar kimia yang sangat tinggi. Dengan adanya penambahan jumlah peserta didik yang memiliki motivasi belajar kimia tinggi dan sangat tinggi serta tidak ada yang memiliki motivasi belajar yang rendah menunjukkan bahwa motivasi belajar peserta didik telah mengalami peningkatan walaupun tidak terlalu signifikan.

Peningkatan motivasi belajar peserta didik juga ditunjukkan oleh hasil angket motivasi peserta didik sebagai berikut.

Tabel 2. Hasil Angket Motivasi Peserta Didik pada Siklus 1

\begin{tabular}{cccc}
\hline No. & Kriteria & $\begin{array}{c}\text { Jumlah peserta } \\
\text { didik }\end{array}$ & Persentase (\%) \\
\hline 1 & Sangat Tinggi & 1 & 4 \\
2 & Tinggi & 13 & 52 \\
3 & Sedang & 11 & 44 \\
4 & Rendah & 0 & 0 \\
5 & Sangat Rendah & 0 & 0 \\
\hline
\end{tabular}

Tabel 2. menunjukkan bahwa sudah tidak terdapat peserta didik yang memiliki motivasi belajar kimia yang rendah. Motivasi belajar kimia telah meningkat jika dibandingkan dengan hasil angket motivasi belajar peserta didik sebelum dilakukan penelitian yang ditunjukkan oleh tabel 4.1.

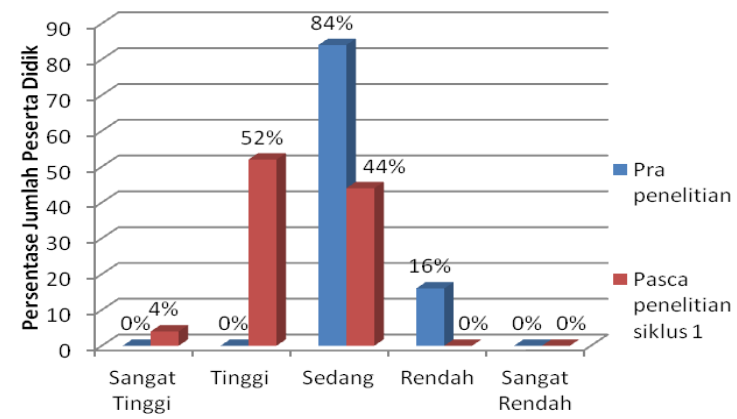

Grafik 1. Perbandingan Hasil

Angket Motivasi Belajar Peserta Didik Sebelum Penelitian dan Setelah Penelitian Siklus Satu
Setelah penyampaian materi pada pertemuan pertama dan kedua selesai, maka peneliti mengadakan tes pada pertemuan ketiga. Tes hasil belajar ini bertujuan untuk mengetahui kemampuan peserta didik dan tingkat keberhasilan penerapan model pembelajaran kooperatif tipe TGT dalam meningkatkan hasil belajar siswa. Tes berupa soal pilihan ganda sebanyak 10 soal dan soal uraian sebanyak 5 soal yang mengacu pada indikator KD 3.3 tentang perkembangan sistem periodik unsur dan sifat keperiodikan unsur. Berikut ini hasil tes belajar peserta didik pada siklus satu setelah diterapkannya model pembelajaran kooperatif tipe TGT.

Tabel 3. Hasil Tes Belajar Peserta Didik pada Siklus 1

\begin{tabular}{llll}
\hline Rentang Nilai & Kategori Nilai & $\begin{array}{l}\text { Jumlah } \\
\text { Peserta Didik }\end{array}$ & Persentase (\%) \\
\hline $90-100$ & A & 2 & 8 \\
$78-89$ & B & 5 & 20 \\
$75-77$ & C & 1 & 4 \\
$<75$ & D & 17 & 68 \\
\hline
\end{tabular}


Berdasarkan tabel 3., persentase peserta didik yang telah mencapai nilai KKM hanya $32 \%$. Persentase tersebut diperoleh dengan cara menjumlahkan persentase peserta didik yang telah tuntas, yaitu $(8+20+4) \%$. Sedangkan persentase peserta didik yang belum mampu mencapai nilai KKM masih sangat banyak, yaitu $68 \%$. Namun, nilai rata-rata secara klasikal meningkat yang semula 48,48 menjadi 75. Masih banyaknya peserta didik yang belum mencapai KKM maka perlu dilakukan perbaikan pada siklus dua.

Pelaksanaan tindakan siklus 2 ini merupakan kelanjutan dari siklus 1 dengan perencanaan dan pelaksanaan proses pembelajaran yang hampir sama dengan siklus 1. Pelaksanaan tindakan siklus 2 dilaksanakan selama tiga kali pertemuan. Satu kali pertemuan terdiri dari tiga jam pelajaran ( $3 \times 45$ menit). Pertemuan pertama dan kedua merupakan tahap penyampaian materi pembelajaran, sedangkan pertemuan ketiga digunakan untuk tes belajar dan penyebaran angket motivasi belajar peserta didik.

Sebelum melakukan penelitian di dalam kelas, peneliti meyiapkan RPP, LKPD, lembar observasi motivasi belajar peserta didik, dan instrumen penilaian. Kelompok diskusi tidak mengalami perubahan, yaitu sebanyak lima kelompok yang terdiri dari lima peserta didik dengan kemampuan heterogen untuk masingmasing kelompok.

Lembar observasi motivasi belajar diberikan kepada observer dengan tujuan memudahkan guru dalam mengamati aktivitas peserta didik sesuai dengan indikator motivasi. Terdapat tiga observer yang ikut terlibat selama proses pembelajaran. Karena jumlah kelompoknya hanya lima maka dua observer mengamati empat kelompok dan satu observer mengamati satu kelompok sekaligus membuat dokumentasi pembelajaran. Untuk memudahkan observer dalam mengamati, maka setiap peserta didik menggunakan nomor absen yang diletakkan di bahu kanannya.

Materi yang diajarkan pada pertemuan pertama dalam siklus 2 adalah materi perkembangan sistem periodik unsur. Sedangkan materi yang diajarkan pada pertemuan kedua adalah kestabilan atom, struktur Lewis, dan ikatan ion. Proses pembelajaran di kelas berjalan sesuai dengan RPP yang menggunakan model pembelajaran kooperatif tipe TGT. Model pembelajaran kooperatif tipe TGT memiliki enam fase, yaitu menyampaikan tujuan dan motivasi peserta didik, menyajikan informasi, mengorganisasikan peserta didik ke dalam kelompok belajar, membimbing kelompok bekerja dan belajar, evaluasi, penghargaan kelompok. Tahapantahapan tersebut tetap mengacu pada pendekatan saintifik (5M). Yang menjadi ciri dari tipe TGT adalah adanya permainan. Permainan dilakukan pada tahap membimbing kelompok bekerja dan belajar. Setelah peserta didik mengkomunikasikan hasil diskusi kelompoknya, maka permainan dapat dimulai.

Guru menginformasikan aturan permainan terlebih dahulu. Dalam permainan, terdapat tiga kelompok. Peserta didik dengan kemampuan kognitif tertinggi di kelompoknya berkumpul dalam Kelompok A. Peserta didik dengan kemampuan kognitif menengah di kelompoknya berkumpul dalam Kelompok B. Peserta didik dengan kemampuan kognitif rendah di kelompoknya berkumpul dalam Kelompok C. Kelompok A, B, C diberi soal sesuai dengan tingkat kognitifnya. Setiap anggota dalam kelompok A, B, C akan saling bersaing mengerjakan soal untuk memberikan poin kepada kelompoknya. Kelompok dengan poin tertinggi akan menjadi pemenang permainan. Pemenang akan mendapatkan penghargaan dari guru pada saat penutup tahap penghargaan kelompok.

Berikut ini adalah hasil observasi motivasi belajar peserta didik pada pertemuan pertama dan kedua.

Tabel 4. Hasil Observasi Motivasi Belajar Peserta Didik pada Siklus 2

\begin{tabular}{cccccc}
\hline No. & Kriteria & \multicolumn{2}{c}{ Pertemuan ke-1 } & \multicolumn{2}{c}{ Pertemuan ke-2 } \\
& & $\begin{array}{c}\text { Jumlah Peserta } \\
\text { Didik }\end{array}$ & $\begin{array}{c}\text { Persentase } \\
\text { (\%) }\end{array}$ & $\begin{array}{c}\text { Jumlah Peserta } \\
\text { Didik }\end{array}$ & $\begin{array}{c}\text { Persentase } \\
\text { (\%) }\end{array}$ \\
\hline 1 & Sangat Tinggi & 7 & 28 & 11 & 44 \\
2 & Tinggi & 18 & 72 & 14 & 56 \\
3 & Sedang & 0 & 0 & 0 & 0 \\
4 & Rendah & 0 & 0 & 0 & 0 \\
5 & Sangat Rendah & 0 & 0 & 0 & 0 \\
\hline
\end{tabular}

Berdasarkan tabel 4, pada pertemuan pertama dalam siklus dua, hasil observasi terhadap motivasi belajar peserta didik menunjukkan bahwa sebanyak $28 \%$ peserta didik yang memiliki motivasi belajar kimia yang sangat tinggi dan sebanyak $72 \%$ peserta didik yang memiliki motivasi belajar kimia yang tinggi. Pada pertemuan kedua, jumlah peserta didik 
yang memiliki motivasi belajar kimia yang sangat tinggi mengalami peningkatan menjadi $44 \%$ sedangkan jumlah peserta didik yang memiliki motivasi belajar kimia yang tinggi mengalami penurunan menjadi 56\%. Persentase motivasi belajar rata-ratanya juga mengalami kenaikan. Pada pertemuan pertama siklus 2, persentase rata-ratanya mencapai nilai sebesar $77 \%$ sedangkan pada pertemuan kedua siklus 2 , persentase rata-ratanya mencapai nilai sebesar $79,2 \%$. Persentase rata-rata tersebut telah termasuk dalam kategori tinggi. Dengan adanya penambahan jumlah peserta didik yang memiliki motivasi belajar kimia sangat tinggi dan tidak ada peserta didik yang memiliki motivasi belajar yang sedang ataupun rendah menunjukkan bahwa motivasi belajar peserta didik telah mengalami peningkatan yang cukup signifikan dari siklus 1 sampai siklus 2 dalam penelitian tindakan kelas.

Perbandingan persentase hasil observasi motivasi belajar peserta didik ratarata dari siklus 1 sampai siklus 2 digambarkan pada grafik berikut.

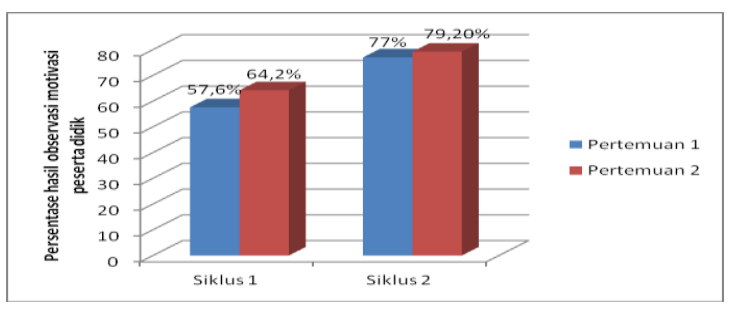

Grafik 2. Perbandingan Persentase Hasil Observasi Motivasi Belajar Peserta Didik Rata-Rata dari Siklus 1 sampai Siklus 2

Berdasarkan grafik 4.2, persentase hasil observasi motivasi belajar peserta didik mengalami peningkatan yang cukup signifikan. Pada siklus satu, persentase motivasi peserta didik rata-rata yang semula hanya $57,6 \%$ saat pertemuan pertama mengalami kenaikan menjadi 64,2\%. Setelah dilakukan penyempurnaan tindakan untuk diterapkan di siklus dua, persentase motivasi peserta didik rata-rata kembali mengalami peningkatan menjadi $77 \%$ pada pertemuan pertama dan $79,2 \%$ pada pertemuan kedua. Hasil akhir dengan persentase $79,2 \%$ sudah termasuk dalam kategori tinggi.

Peningkatan motivasi belajar peserta didik juga ditunjukkan oleh hasil angket motivasi peserta didik sebagai berikut.

Tabel 5. Hasil Angket Motivasi Peserta Didik pada Siklus 2

\begin{tabular}{cccc}
\hline No. & Kriteria & $\begin{array}{c}\text { Jumlah peserta } \\
\text { didik }\end{array}$ & Persentase (\%) \\
\hline 1 & Sangat Tinggi & 7 & 28 \\
2 & Tinggi & 18 & 72 \\
3 & Sedang & 0 & 0 \\
4 & Rendah & 0 & 0 \\
5 & Sangat Rendah & 0 & 0 \\
\hline
\end{tabular}

Tabel 5. menunjukkan bahwa sudah tidak terdapat peserta didik yang memiliki motivasi belajar kimia yang sedang maupun rendah. Sebanyak 28\% dari peserta didik yang telah memiliki motivasi belajar kimia yang sangat tinggi dan sebanyak $72 \%$ dari peserta didik yang telah memiliki motivasi belajar kimia yang tinggi. Motivasi belajar kimia telah meningkat jika dibandingkan dengan hasil angket motivasi belajar peserta didik sebelum dilakukan penelitian yang ditunjukkan oleh tabel 1. dan hasil angket motivasi pada siklus 1 yang ditunjukkan oleh tabel 2.

Persentase rata-rata dari hasil angket motivasi belajar peserta didik pada pelajaran kimia sebelum penelitian, setelah penelitian siklus satu, dan siklus 2 terus mengalami peningkatan yang ditunjukkan oleh grafik berikut ini.

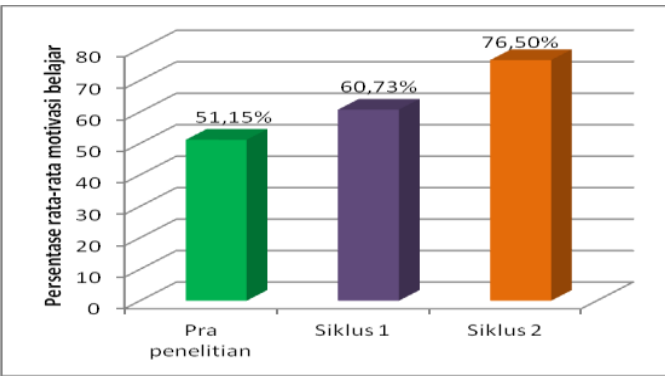

Grafik 3. Perbandingan Persentase

Rata-rata Hasil Angket Motivasi Belajar Peserta Didik Pra Penelitian, Siklus 1, dan Siklus 2

Sebelum dilakukan penelitian, persentase rata-rata motivasi belajar peserta didik adalah 51,15\%. Persentase tersebut terus meningkat setelah dilakukan penelitian tindakan kelas dengan menggunakan model pembelajaran kooperatif tipe TGT (Teams Games Tournament). Persentase rata-rata motivasi belajar peserta didik pada siklus satu telah mencapai $60,73 \%$ dan pada siklus dua telah mencapai $76,50 \%$ 
yang termasuk dalam kategori tinggi.

Setelah penyampaian materi pada pertemuan pertama dan kedua selesai, maka peneliti mengadakan tes pada pertemuan ketiga. Tes hasil belajar ini bertujuan untuk mengetahui kemampuan peserta didik dan tingkat keberhasilan penerapan model pembelajaran kooperatif tipe TGT dalam meningkatkan hasil belajar siswa. Tes berupa soal pilihan ganda sebanyak 10 soal dan soal uraian sebanyak 5 soal yang mengacu pada indikator KD 3.5 tentang ikatan kimia. Berikut ini hasil tes belajar peserta didik pada siklus dua setelah diterapkannya model pembelajaran kooperatif tipe TGT.

Tabel 6 Hasil Tes Belajar Peserta Didik pada Siklus 2

\begin{tabular}{cccc}
\hline Rentang Nilai & Kategori Nilai & $\begin{array}{c}\text { Jumlah } \\
\text { Peserta Didik }\end{array}$ & Persentase (\%) \\
\hline $90-100$ & A & 7 & 28 \\
$78-89$ & B & 11 & 44 \\
$75-77$ & C & 3 & 12 \\
$<75$ & D & 4 & 16 \\
\hline
\end{tabular}

Berdasarkan tabel 6., persentase peserta didik yang mendapat nilai A sebanyak $28 \%$, nilai B sebanyak $44 \%$, nilai C sebanyak $12 \%$, dan nilai D sebanyak $16 \%$. Peserta didik yang dianggap tuntas atau telah memenuhi nilai KKM adalah peserta didik yang mendapat nilai A, B, dan C. Persentase ketuntasan secara klasikal sebanyak 84\%. Jika dibandingkan dengan nilai UTS, dan hasil belajar siklus satu, hasil belajar pada siklus dua telah mengalami peningkatan yang cukup signifikan. Berikut ini grafik perbandingan nilai rata-rata tes hasil belajar peserta didik.

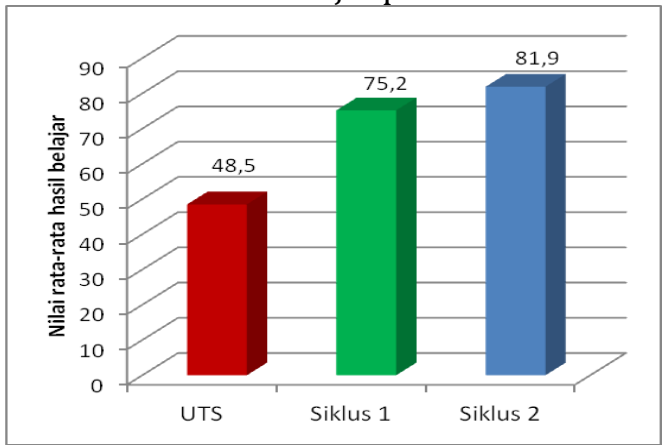

\section{Grafik 4. Perbandingan Nilai Rata-Rata Hasil Belajar UTS, Siklus 1, dan Siklus 2}

Grafik 4.4 menunjukkan bahwa dengan penerapan model pembelajaran kooperatif tipe TGT dapat meningkatkan hasil belajar peserta didik secara bertahap sehingga 84\% peserta didik mampu mencapai nilai KKM, yaitu 75 .

Secara kesuluruhan tujuan dalam penelitian ini telah tercapai, yaitu (1) Motivasi belajar peserta didik telah termasuk dalam kriteria tinggi dengan persentase rata-rata $79,2 \%$ berdasarkan hasil observasi dan 76,5\% berdasarkan angket motivasi belajar peserta didik. (2) Hasil belajar peserta didik mengalami peningkatan yang ditunjukkan oleh persentase ketuntasan klasikal sebesar $84 \%$.

Sebagai data pendukung tentang keberhasilan penerapan model pembelajaran kooperatif tipe TGT untuk meningkatkan motivasi dan hasil belajar peserta didik maka peneliti memberikan angket respon peserta didik terhadap pembelajaran yang dilaksanakan dalam PTK ini. Hasil angket respon menujukkan bahwa hampir semua peserta didik merasa senang dengan penerapan model pembelajaran kooperatif tipe TGT. Persentase rata-rata dari hasil angket respon peserta didik kelas X MIA 2 sebesar $85,52 \%$ yang termasuk dalam kategori baik. Dengan menerapkan model pembelajaran yang membuat peserta didik merasa nyaman dan tidak tertekan maka secara tidak langsung akan berakibat pada motivasi belajar peserta didik, yakni dapat meningkatkan motivasi belajar peserta didik. Semakin tinggi motivasi belajar peserta didik maka kemungkinan hasil belajarnya juga naik semakin besar.

\section{Pembahasan}

Hasil penelitian tindakan kelas ini mampu mencapai tujuannya, yaitu meningkatkan motivasi dan hasil belajar peserta didik pada mata pelajaran kimia kelas X. Peningkatan motivasi belajar peserta didik ditunjukkan oleh hasil observasi motivasi peserta didik yang mengalami peningkatan dari siklus satu ke siklus dua dengan persentase hasil pada siklus satu sebesar $16 \%$ untuk pertemuan satu dan 28\% untuk pertemuan dua dalam kategori tinggi. Sedangkan kategori sangat tinggi dicapai pada pertemuan dua saja dan hanya sebesar $8 \%$ dari jumlah peserta didik. Persentase hasil pada siklus dua sebesar $72 \%$ untuk pertemuan satu dan $56 \%$ untuk pertemuan dua dalam kategori tinggi. Sedangkan kategori sangat tinggi dicapai pada pertemuan satu dengan persentase sebesar $28 \%$ dan pertemuan kedua sebesar $44 \%$ dari jumlah peserta didik. Peningkatan motivasi belajar peserta didik juga ditunjukkan dengan 
meningkatnya hasil angket motivasi belajar dari pra penelitian hingga siklus 2. Persentase ratarata hasil angket motivasi pra penelitian sebesar $51,15 \%$ dengan kategori sedang, persentase rata-rata hasil angket motivasi siklus 1 sebesar $60,73 \%$ dengan kategori tinggi, dan persentase rata-rata hasil angket motivasi siklus 2 sebesar $76,5 \%$ dengan kategori tinggi.

Peningkatan hasil belajar peserta didik ditunjukkan dengan hasil tes yang diadakan setiap akhir siklus. Pada siklus 1, persentase ketuntasan hasil belajar peserta didik sebesar $32 \%$. Sedangkan pada siklus 2telah mengalami peningkatan yang cukup signifikan, yaitu dengan persentase ketuntasan hasil belajar peserta didik sebesar $84 \%$.

Angket respon peserta didik terhadap penerapan model pembelajaran kooperatif tipe TGT menghasilkan persentase rata-rata $85,52 \%$ yang termasuk dalam kategori baik. Hasil angket ini digunakan sebagai data pendukung keberhasilan penerapan model pembelajaran kooperatif tipe TGT dalam meningkatkan motivasi dan hasil belajar peserta didik.

Hasil refleki siklus satu peneliti menemukan beberapa kendala serta solusi untuk dilaksanakan pada siklus dua, yaitu : (1), Pembagian kelompok yang baru membuat peserta didik masih enggan untuk saling bekerja sama dengan baik antar sesama anggota kelompok sehingga diskusi kurang berjalan lancar. Pembagian kelompok ini memang dilakukan agar dalam setiap kelompok terdiri dari peserta didik dengan kemampuan heterogen. Hal ini berkaitan dengan permainan yang akan dilaksanakan. Dalam permainan nanti, setiap perwakilan kelompok akan bersaing dengan kelompok lain yang memiliki kemampuan kognitif yang hampir sama sehingga persaingan akan terasa lebih adil. Soal dalam permainan pun dibuat sesuai dengan tingkat kognitif. Kelompok permainan yang memiliki tingkat kognitif yang lebih tinggi maka akan mendapatkan soal permainan yang lebih sulit. (2), Pada siklus dua, kelompok yang digunakan tetap kelompok pada siklus satu. Peserta didik hanya perlu beradaptasi dengan anggota kelompok barunya sehingga mereka dapat saling bekerja sama dalam menyelesaikan LKPD. (3), Model pembelajaran yang digunakan guru merupakan model pembelajaran baru bagi peserta didik sehingga peserta didik masih terlihat mengalami kebingungan dalam melaksanakan tahapan dalam kegiatan pembelajaran. Dengan diterapkannya model pembelajaran kooperatif tipe TGT secara berkelanjutan sampai siklus dua, maka peserta didik akan mulai terbiasa. Dalam hal ini tugas penting guru adalah selalu mengarahkan peserta didik agar sesuai dengan sintaks model pembelajaran. (4), Ada beberapa peserta didik yang kurang aktif dan tidak mau bertanya kepada guru ketika ada materi yang kurang dipahami sehingga nilai hasil tes belajarnya belum mampu mencapai KKM. Solusi untuk memperkecil kemungkinan tersebut terjadi pada siklus dua adalah dengan cara guru mendekati peserta didik dan menanyakan materi mana yang belum dipahami atau dengan memberikan umpan/pertanyaan kepada peserta didik yang kurang aktif pada saat guru memberi penguatan sehingga guru tahu bagian materi yang belum dimengerti oleh peserta didik tersebut. (5), Kemauan peserta didik untuk membuat pertanyaan pada fase menanya masih didominasi oleh peserta didik yang aktif saja, yaitu yang memiliki motivasi belajar tinggi. Untuk mengatasi hal tersebut, maka guru hanya memberikan satu kesempatan kepada setiap peserta didik untuk menyampaikan pertanyaan sehingga diharapkan pada saat siklus dua, peserta didik yang bertanya tidak hanya peserta didik yang aktif saja.

\section{Simpulan}

Penerapan model pembelajaran kooperatif tipe TGT dalam pembelajaran kimia dapat meningkatkan motivasi dan hasil belajar peserta didik kelas X MIA 2 SMA Negeri 3 Singaraja Tahun Ajaran 2016/2017 dengan persentase rata-rata motivasi belajar meningkat dari pra penelitian hingga siklus 2, yaitu 51,15\% menjadi $60,73 \%$ pada siklus 1 dan menjadi $76,5 \%$ pada siklus 2 . Hasil tes belajar peserta didik juga mengalami peningkatan dari 32\% pada siklus satu menjadi $84 \%$ pada siklus dua. Peningkatan motivasi dan hasil belajar peserta didik didukung dengan data persentase keseluruhan hasil angket respon peserta didik terhadap model pembelajarn kooperatif tipe TGT, yaitu sebanyak $85,52 \%$. Penerapan model kooperatif tipe TGT dapat digunakan sebagai salah satu alternatif model pembelajaran bagi guru dalam proses pembelajaran. Namun, model pembelajaran ini membutuhkan waktu yang lebih banyak dalam proses pembelajarannya karena adanya permainan. Maka dari itu, guru dituntut untuk bisa membagi waktu dalam penyampaian materi yang sesuai dengan indikator pencapain kompetensi.

\section{Daftar Pustaka}

A'la, Miftahul.2011.Quantum Teaching (Buku pintar dan praktis).Yogjakarta: Diva Press.

Dimyati dan Mudjiono.2006.Belajar dan Pembelajaran. Jakarta: Rineka Cipta.

Hamalik, Oemar.2004.Proses Belajar Mengajar.Jakarta: Bumi Aksara. 
Riduwan.2012. Skala Pengukuran VariabelVariabel Penelitian. Bandung: CV Alfabeta.

Rusman.2011.Model-Model

Pembelajaran.Depok: PT. Rajagrafindo Persada

Sardiman, A.M.2007.Interaksi dan Motivasi Belajar Mengajar.Jakarta: Rajawali Pers.

Slavin, Robert E. 2005. Cooperative Learning: Teori, Riset, dan Praktik. Diterjemahkan oleh Narulita Yusron. 2010. Bandung: Nusa Media.

Sudjana, Nana.2002.Penilaian Hasil Proses Belajar Mengajar.Bandung: Remaja Rosdakarya.

Sugihartono, dkk. 2007.Psikologi Pendidikan. Yogyakarta: UNY Press.

Suprijono, Agus.2009.Cooperative Learning: Teori dan Aplikasi PAIKEM.Yogjakarta: Pustaka Belajar.

Taniredja, T., Faridli, E., dan Harmianto, S. 2013.Model-model pembelajaran

inovatif dan efektif. Edisi keempat. Bandung: Alfabeta.

Trianto. 2009. Mendesain Model Pembelajaran Inovatif Progresif: Konsep, Landasan, dan Implementasinya pada Kurikulum Tingkat Satuan Pendidikan (KTSP). Jakarta: Kencana.

Yorks, Lyle.1976.A Radical Approach to Job Enrichment.New York: Amacom. 